\section{International Scientific Journal Theoretical \& Applied Science}

p-ISSN: 2308-4944 (print) e-ISSN: 2409-0085 (online)

Year: $2016 \quad$ Issue: 1 Volume: 33

Published: $30.01 .2016 \quad \underline{\text { http://T-Science.org }}$
Timur Al'bertovich Magsumov

$\mathrm{PhD}$ (History), Associate Professor International Network Center for Fundamental and Applied Research, Russian Federation Naberezhnye Chelny State Pedagogical University,

Russian Federation nabonid1@yandex.ru

SECTION 17. World history. History of science and technology.

\title{
«O BEDNOM UCHASHCHEMSYA ZAMOLVITE SLOVO»: COLLECTIVE FORMS OF SUPPORT TO THE NEEDY PUPILS IN LATE RUSSIAN EMPIRE
}

\begin{abstract}
Using the comparative analysis of normative documents and methodical делопроизводственной documentation, the author examines the legal and practical aspects of the structure and functioning, efficiency of activity of welfare to the needy students in secondary vocational training institutions of pre-revolutionary Russia. Special attention is paid to the analysis of the composition, the organization of work and the main directions of their activity. The conclusion is made about the effectiveness of Companies, in spite of a clearly defined state control. Through the prism of the activity of the author considers the specificity of the interaction and complementarity of public and authorities in the sphere of education. It is emphasized, that, thanks to the creation of charitable societies in schools, became possible внесословная social assistance, partly ensuring the vertical social mobility in a modernizing society.

Key words: charity, education, Russian Empire, the Society of welfare to the needy students.

Language: Russian

Citation: Magsumov TA (2016) «O BEDNOM UCHASHCHEMSYA ZAMOLVITE SLOVO»: COLLECTIVE FORMS OF SUPPORT TO THE NEEDY PUPILS IN LATE RUSSIAN EMPIRE. ISJ Theoretical \& Applied Science, 01 (33): 127-136.

Soi: http://s-o-i.org/1.1/TAS-01-33-22 Doi: crossef http://dx.doi.org/10.15863/TAS.2016.01.33.22

\section{«О БЕДНОМ УЧАЩЕМСЯ ЗАМОЛВИТЕ СЛОВО»: КОЛЛЕКТИВНЫЕ ФОРМЫ ПОДДЕРЖКИ НУЖДАЮЩИХСЯ УЧЕНИКОВ В ПОЗДНЕИМПЕРСКОЙ РОССИИ}

Аннотация: Используя сравнительный анализ нормативных документов и учебноделопроизводственной документации, автор исследует правовые и практические аспекты устройства и функиионирования, эффективность деятельности Обществ вспомощчествования нуждающимся учащцимя при средних профессиональных учебных заведениях дореволюиионной России. Особое внимание уделено анализу составов, организации работы и основных направлений их деятельности. Делается вывод об эффективности работы Обществ, несмотря на четко поставленный государственный контроль. Сквозь призму деятельности Обществ автор рассматривает специфику взаимодействия и взаимодополнения власти и общественности в сфере образования. Подчеркивается, что, благодаря созданию благотворительных обществ при школах, стала возможной внесословная социальная помощь, частично обеспечившая вертикальную сочиальную мобильность в модернизирующемся обществе.

Ключевые слова: благотворительность, образование, Российская империя, Общество вспомоществования нуждающимся учащимся.

\section{Введение}

Система образования, как и вся социальная сфера, в нашей стране всегда находилась на государственном обеспечении, зачастую недостаточном даже для покрытия текущих расходов, не говоря уже о дальнейшем совершенствовании. Одной из перспективных линий развития профессиональной школы в современной России, в частности, автономных образовательных учреждений, становится формирование и развитие системы благотворительности и попечительства, механизмов привлечения пожертвований, создание специализированных фондов поддержки развития учебных заведений, 
инновационных предприятий на базе профессиональных учебных заведений.

Историческая наука в этом процессе также нашла свою нишу. Дело в том, что появление всех этих форм поддержки и развития отечественной школы имеет не столько характер заимствования западных моделей, сколько исторически заданное направление использования дореволюционного опыта. В России во второй половине XIX - начале XX в. меценатская деятельность получила исключительно широкий размах. Отечественная дореволюционная провинциальная школа накопила огромный опыт взаимодействия и сотрудничества с органами местного самоуправления, общественностью и отдельными представителями регионального социума [см., напр.: 16; 19; 21].

\section{Обсуждение проблемы}

Проявления активности местных властей, отдельных благотворителей, попечителей и попечительных советов учебных заведений в устройстве и содержании школ, их финансовой поддержке отдельных учебных заведений нашли отражение в целом комплексе разнохарактерных работ профессиональных историков, краеведовлюбителей, журналистов и других представителей интеллигенции $[14 ; 15 ; 17 ; 18 ; 28$; 30]. В статье мы остановимся только на одной форме, ставшей в исследованиях школьной благотворительности всего лишь небольшим примером проявления меценатства. Речь идет об Обществах вспомоществования нуждающимся учащимся (далее Общества) конкретным учебным заведениям (в отличие от Обществ, существовавших в ряде городов, особенно в Сибири, и охватывавших все учебные заведения города). Сразу оговоримся, что недостаточное внимание исследователей к данной проблеме не ставится нами им в укор, поскольку, при зачастую большом количестве членов Обществ, финансовая сторона их помощи была действительно малозаметной в огромном потоке средств образовательного меценатства, а также потому, что в отличие от всплеска благотворительности в народном образовании начиная с эпохи Великих реформ, Общества, как организационная форма, возникли значительно позже - в самом конце XIX столетия. Однако изучение этой проблемы поможет раскрыть некоторые особенности благотворительности в сфере образования [29; 33].

\section{Результаты}

Общества

вспомоществования нуждающимся учащимся стали появляться через некоторое время после открытий учебных заведений, поскольку потребность в них возникала постепенно, а в негосударственной школе при ее создании первоочередными были значительные финансовые вливания на постройку зданий и создание материальной базы. Если говорить об учебных заведениях г. Казани, то при Казанской торговой школе (далее КТШ), открытой в 1910 г, вспомоществования было учреждено в 1913 г., при Казанском речном училище (далее КРУ) (открыто в 1904 г.) Общество стало действовать в 1908 г., при Казанском коммерческом училище (далее ККУ) (открыто в 1905 г.) Общество начало деятельность в 1911 г. [3, с. $3 ; 7$, с. $1 ; 1$, с. 81]. Тем не менее, попытки оказания помощи ученикам предпринимались еще до создания Обществ, в том числе через иные организации. Так, в 1899 г. при Казанском промышленном училище (далее КПУ) было открыто, согласно Высочайше утвержденному мнению Государственного совета, Особое попечительство, цель которого заключалась в заботе о материально-техническом развитии училища, отстаивании его интересов в вышестоящих инстанциях, трудоустройстве выпускников (Общество вспомоществования при училище начало свою деятельность в 1903 г.) [22, л. 2]. В первые годы работы попечительство выполняло функции Общества вспомоществования нуждающимся учащимся, потратив на эти цели к 1 января 1908 г. 1 276,5 руб.; кроме того, за этот период попечительство собрало 1716,33 руб. на устройство предполагавшегося общежития [26, л. 33об.].

По официальным данным, всех Обществ такого типа в стране к 1897 г. (27 ноября 1897 г. МВД был принят типовой Устав Обществ вспомоществования нуждающимся учащимся) было 539 [11]. Устав предполагал широкий спектр деятельности Обществ, охватывающий все возможные варианты материальной помощи учащимся в жизни, обучении и быте. По сути Общества вспомоществования должны были выполнять одну из непрямых узких функций попечительных советов - оказание помощи нуждающимся ученикам. C их появлением возникло четкое организационное разделение общественной помощи в отношении отдельных образовательных учреждений на два вида общественных организаций: попечительный совет, помогавший школе, и Общество вспомоществования, поддерживающее «недостаточных» (нуждающихся) учащихся. Именно поэтому в негосударственной школе выдвижением идей об учреждении и организационными вопросами создания Обществ занимались попечительные советы при участии педсоветов (так было, например, в ККУ. См.: [1, c. 80]), в государственной школе эти проблемы генерировались в руках педагогических советов 
(это легко прослеживается не только по протоколам заседаний попечительных и педагогических советов, но и косвенно по составу членов-учредителей Обществ. См., напр.: [32, л. 9об.]. Так, из 17 членов учредителей Общества при КРУ трое были действующими и пятеро - бывшими членами попечительного совета, а девять человек - работниками училища [7, c. 22-23]. В 1901 г. по предложению ряда членов педагогического совета КПУ был возбужден вопрос об организации «Общества вспомоществования нуждающимся учащимся при Казанском промышленном училище». Был выработан Устав Общества, который был утвержден в 1902 г., а с 1903 г. Общество начало свою деятельность [26, л. 32об.]). Причина вычленения Обществ из попечительных советов в отдельные организации была чисто утилитарная, открыто об этом сказано в историческом очерке «Десятилетие Казанского коммерческого училища. 1905-1915»: «Попечительный Совет вначале освобождал от платы за право учения особо нуждающихся, но впоследствии такой порядок не мог удовлетворить всех нуждающихся без нарушения равновесия в бюджете. Тогда явилась мысль об учреждении при училище Общества вспомоществования» [1, c. $80-81]$.

Каждое Общество имело точно очерченную сферу своей деятельности - попечение о недостаточных учащихся конкретно своего училища $[27$, л. $182 ; 7$, с. $1 ; 4$, с. 1$]$. Заметим, что в уставах Обществ отдельным примечанием планировалась на перспективу единовременная финансовая помощь решившим продолжить дальнейшее образование выпускникам из тех, кто «заслуживает того по их поведению, по выдающимся способностям и успехам, засвидетельствованным училищным начальством» $[10, \quad$ c. $10 ; 27, \quad$ л. 182]. Эта перспектива описывалась, например, и в первых изданиях «Кратких сведений о Казанском промышленном училище», однако, в последующих изданиях этой брошюры мы уже не обнаружили такой фразы, не было сведений о помощи выпускникам и в просмотренных нами ряде отчетов Обществ по КУО. Скорее всего, скромные средства Обществ вспомоществования, которых не хватало на финансовую поддержку своих учащихся, не позволяли помогать бывшим ученикам, уже получившим образование.

Основные направления деятельности Обществ также четко фиксировались в их Уставах. Помощь любого Общества могла выражаться в следующих направлениях деятельности:

1. Взнос платы за учение. Для большинства Обществ эта статья расходов была основной. Так, из всей суммы расходов Общества при ККУ за
1912-1913 учебный год в 2328,01 руб. взносы за право учения составили 1 221,25 руб. или 83,38 \% всех расходов [2, с. 9].

2. Бесплатная выдача книг и учебных пособий (естественно, из числа одобренных Учебным отделом профильного министерства и МНП) или их продажа по удешевленной цене. Бесплатная выдача книг вовсе не означала их дарения, в финансовых сметах расходов и баланса часто иногда мы встречали суммы под статьей «библиотека учебников», порой сведения о библиотеке учебников встречались и в отчетах правления. Так, в 1911 г. в библиотеке Общества при Симбирском коммерческом училище (далее СимКУ) числилось 84 названия в 428 книгах на сумму приблизительно 406,3 руб. [5, с. 5]. Соотнеся количество наименований и экземпляров, нетрудно понять, что библиотека была заполнена в основном учебниками. Получается, что книги выдавались на время, и после окончания учебного года передавались учащимися обратно в библиотеку Общества для последующего использования другими нуждающимися.

3. Снабжение неимущих одеждой, пищей, жильем, медицинской помощью (обеспечение медицинскими пособиями под наблюдением врача на дому, помещение в больницу) и содействие к погребению умерших. В 1904 г., например, правление Общества при Казанском земледельческом училище оказало помощь девяти беднейшим учащимся, выдав им в общей сложности 210 руб. для взноса за содержание в пансионе училища (и, увы, это была единственная статья расходов Общества за указанный год) [9, с. 4].

4. Назначение «в исключительных случаях денежных пособий» $[24, \quad$ с. 21-21об.]. В зависимости от размера общественной организации и имеющегося у нее капитала денежные пособия поволжских Обществ составляли от 5 до 30 руб. Количество учеников, которым оказана помощь, также зависело от доходов Общества.

Самое главное, на что нам хотелось бы обратить внимание, это то, что в своей реальной работе большинство Обществ смогли задействовать все направления, предусмотренные уставом.

Значимым крупным проектом, удачно реализованным рядом Обществ, была организация специальных столовых для учащихся. Столовая при КПУ была открыта в октябре 1907 г. во многом благодаря поддержке председателя Общества Н.Н. Киселева, который на свои средства приобрел для нее все необходимое оборудование. Здесь давали недорогие и сытные обеды за небольшую плату или же бесплатно, за счет Общества. За 12 коп. 
учащийся получал горячий обед из мясного супа и каши или картофеля, а за 15 коп. - обед из двух мясных блюд [26, л. 33]. Однако и до этого времени в училище старались организовать питание учеников. Уже по данным за 1902 г. мы видим, что ученики получали за умеренную плату молоко с хлебом, и для них организовывалось доставление горячих завтраков $[25$, л. 1$]$.

Редким проектом Обществ были попытки создания общежитий при учебных заведениях, их не имевших. Так, в 1905-1906 гг. Общество при КПУ активно работало над созданием общежития на 30 человек, 25 из которых жили бы там по льготной цене, а пять - бесплатно. Была собрана сумма в 3700 руб., подыскано здание и подобран персонал, однако, волнения 1905 г. в Казани заставили администрацию отказаться от устройства общежития [20, л. 148], поскольку совместное проживание трех десятков юношей могло способствовать их неформальному объединению, быстрому распространению среди них политических идей и настроений, вплоть до участия в деятельности каких-либо политических организаций.

Не удаляясь от этого вопроса необходимо упомянуть о стипендиальной поддержке, которая сушествовала при большинстве учебных заведений, и была, по сути, еще одной формой помощи бедным ученикам. Так, при КПУ к 1907 г. было учреждено 13 стипендий в среднем по 200 руб. каждая, при ККУ за первые 10 лет существования училища были учреждены четыре стипендии на общую сумму 9300 руб. [8, с. 9-10; 1, с. 80]. Независимо от этого количества стипендий, от оплаты освобождались дети, родители которых проработали в средних и низших учебных заведениях профильного министерства не менее 10 лет [23, л. 9].

При оказании Обществами помощи учащимся должны были приниматься во внимание не только степень их нужды, но и прилежание, и хорошее поведение, засвидетельствованные начальством учебного заведения. Получается, что основные направления деятельности Обществ были поставлены под полный контроль школьной администрации, т.е. без согласования каждой кандидатуры с директором или инспектором Общество не могло оказать помощь ученику. Нарушив это условие, материальной поддержки лишился будущий историк российской провинции В.Ф. Кудрявцев, вынужденный в 1863 г. покинуть Вятскую духовную семинарию. Вторую часть условия - прилежание и хорошее поведение - можно рассматривать как требование педагогическое и политическое. Материальная помощь должна была выступать фактором стимулирования самосовершенствования личности ученика и одновременно условием его политической благонадежности в будущем.

C ходатайством о вспомоществования должны были обращаться родители или заменяющие их лица непосредственно в Правление Общества или через начальство учебного заведения [27, л. $183 ; 7$, с. 3 ; 4, с. 2]. Вполне естественно, что делалось это по второму сценарию - через школьную администрацию, поскольку необходимо было ее заверенное согласие на оказание помощи (кстати, на большинстве прошений, имеющихся в архивохранилищах, мы встречали визы руководителя учебного заведения), ну и по причине того, что членов Правления Общества застать в школе было не всегда возможно (откровенно - проблематично). В единственном из рассмотренных учебных заведений - КРУ мы встретили частые факты того, что заявленияходатайства писали и подписывали сами учащиеся, а не их родители. Связано, это понашему мнению, и с возрастом учеников, и с тем, что большинство происходили из других губерний, и, главное, со спецификой учащихсяречников, совершенно особого, более свободного и, скажем прямо, независимого и непослушного слоя ученичества.

Членство в Обществах не ограничивались количественным максимумом, половыми, сословными и вероисповедными признаками. Членами Обществ не могли быть лишь состоящие на действительной военной службе нижние воинские чины и юнкера, лица, ограниченные в правах по суду, а также учащиеся (исключая посещающих академию офицеров и лиц, окончивших ВУЗы, но продолжающих образование) $[12$, с. $3 ; 7$, с. 3 ; 4,c. 2-3]. Отсутствие полового ценза для членства сыграло, на наш взгляд, весьма положительную роль в финансировании и активной деятельности Обществ. Сразу оговоримся, что, ознакомившись с составом членов Обществ, мы заметили факт того, что абсолютное большинство женщинчленов Обществ были женами членов попечительных советов, представителей администрации и педагогов учебных заведений, при которых создавались Общества, а также местной элиты. Не вдаваясь в причины этого явления, отметим, что многие жены состояли в Обществах наряду с мужьями, т.е. приносили Обществам дополнительный доход, присутствовали не только на общих собраниях, но и были членами и даже председательницами правлений (как, например, жена директора ККУ А.И. Немировская, возглавлявшая Общество при училище $[1$, с. 81$])$, и располагая большим, в сравнении с мужьями, свободным временем, могли уделять делам Обществ пристальное внимание, участвуя в основных мероприятиях по 
привлечению средств (особую активность в качестве дам-распорядительниц женщины проявляли в организации вечеров и концертов [2, c. 8]) и внедряя целые благотворительные проекты, как, например, организация завтраков. Так, в частности, из 29 пожизненных членов Общества при ККУ (на 1913 г.) четверо были женщинами, и при этом женами пожизненных членов - директора училища и трех казанских предпринимателей, а при КТШ (на 1914 г.) из 24 пожизненных членов семеро были женщинами, шестеро из них - жены других пожизненных членов, кроме одной - Е.П. Карякиной (по всей видимости, вдовы депутата Государственной думы В.А. Карякина, усилиями которого дефакто школа и была открыта) [3, с. 9; 2, с. 12]. Общества вспомоществования в частности и благотворительность и попечительство в целом дали женщинам возможность заниматься общественно значимой деятельностью, проявить себя на руководящих должностях, что повышало их социальный статус и роль в местной общественной жизни.

Отсутствие вероисповедного ценза играло важную роль не только в привлечении дополнительных средств для Обществ, но и было жизненной необходимостью, особенно в коммерческих учебных заведениях, где был большой процент учеников не православных исповеданий. Да и что только мог значить для эффективной рекламы, например, Общества при ККУ, факт вхождения в его состав художника и педагога, создателя складной татарской азбуки Ш.А. Тагирова (1858-1918) и председателя хозяйственного правления еврейского молельного дома А.З. Персона, во многом усилиями которого у казанских евреев появилась собственная синагога $[2$, с. 12,16$]$.

В Обществах было предусмотрено два или три вида членства. Сличение ряда уставов Обществ при средних профессиональных учебных заведениях России показало, что эти два варианта видов членства не зависели ни от географического расположения, ни от времени возникновения, ни от ведомственной принадлежности учебного заведения, ни от его организационно-правовой формы. Скорее всего, третий вида членства в ряде Обществ был призван привлечь как можно большее количество лиц, сочувствующих делу образования и стремящихся оказать посильную помощь учебному заведению и учащимся. Итак, члены Обществ обычно подразделялись на почетных и действительных. Почетными могли стать лица, сделавшие значительные пожертвования Обществу или оказавшие ему существенные услуги и избранные в это звание общим собранием. Действительными членами состояли лица, вносившие в кассу Общества не менее трех рублей, или внесшие единовременно определенную, не менее чем на порядок большую, сумму (в разных Обществах от 30 до 60 руб.). Независимо от уплаты денежных взносов, общее собрание могло присвоить звание действительного члена лицу, безвозмездным своим трудом содействующим цели Общества. В Уставе Общества при КРУ этот список уточнялся: медики, бесплатно обслуживавшие бедных больных; учителя, безвозмездно обучавшие находящихся на попечении Общества детей; лица, взявшие на содержание или воспитание кого-либо из бедных или изучавшие действительное положение нуждающихся; поскольку отчеты большинства Обществ и бланки их документации печатались бесплатно, за счет типографий, то и их хозяев в благодарность принимали в действительные члены, тоже касается и лиц, бесплатно ведших бухгалтерию Обществ [7, с. $4 ; 5$, с. $5-6 ; 2$, с. 8]. Лица, вносившие меньшую сумму (от одного до трех рублей), становились членамисоревнователями. Они не пользовались на общем собрании правом решающего голоса, и не могли избираться на должности по Обществу. В случае неуплаты в течение года членского взноса, члены считались выбывшими из Общества, с сохранением права вновь вступить в него на общих основаниях. По постановлению общего собрания члены могли быть исключены из Общества, если их действия нарушали его интересы [27, л. 183-183об.; 7, с. 4-6; 4, с. 3-4; 13, c. 4-5].

Не отрицая огромной роли отдельных меценатов в развитии российской благотворительности, усилиями которых этот феномен получил мировую известность, все же, исходя из вышесказанного, констатируем, что благотворительность конца XIX - начала XX века стала действительно явлением массовым, характерным для целых социальных групп.

Поиск и получение финансовоматериальных средств являлись приоритетной задачей деятельности всех благотворительных обществ, поскольку успешность работы организации напрямую зависела от поступлений денежных средств, которые впоследствии вкладывались в развитие образования в регионе. Именно поэтому главным предметом заботы Обществ в первые годы их существования являлось изыскание средств для их деятельности. За первый год своей деятельности Общество при КТШ смогло собрать неплохую сумму - 1216,06 руб., расходы же Общества составили всего 213,96 руб. [3, с. 20-21, 26]. Это во многом было обеспечено поддержкой попечительного совета, выраженной словами А.Д. Черноярова: «В нынешнем году попечительный совет постарается сам освободить учеников 
недостаточных родителей от платы за учение, а в будущем году Общество вспомоществования должно взять это бремя на себя. $<\ldots>$ А сейчас следует подкопить денег. Вперед тратить, будут ошибки» [3, с. 15]. Кроме этого, Общество освободило частично или полностью 12 учеников от платы за учение, оказывало помощь нуждающимся ученикам в виде одежды, обуви, лекарств и учебников [3, с. 4-5].

$$
\text { Согласно Уставам финансово- }
$$

имущественные средства Обществ

формировались за счет:

1) членских взносов. Они были основным и стабильным источником поступлений в казну Обществ. Так, они составляли 65,12\% (792 руб.) прихода Общества при КТШ за 1914 г., 26,17 \% (558 руб.) прихода Общества при ККУ за 1912-1913 учебный год [3, c. 20; 2, с. 9] (существенная разница в процентом отношении членских взносов в двух Обществах связана с тем, что Общество при КТШ действовало первый год, поэтому практически не имело иных источников дохода);

2) пожертвований членов Обществ и посторонних лиц деньгами или соответствующими целям Обществ вещами (суммы пожертвований обычно были весьма незначительными; если говорить о посторонних лицах, то зачастую для них такая акция была разовой или же сумм пожертвования было недостаточно для ежегодного членского взноса; в отношении пожертвований членов Общества напрашивается вывод о том, что, поскольку дополнительных пожертвований они не делали, то получается, с одной стороны, почетные члены считали достаточным свой необходимый для этого статуса единовременный взнос, а действительные члены либо не имели средств для большого единовременного взноса с целью получения почетного членства, либо также воспринимали свои взносы как достаточный вклад в дело Общества);

3) доходов от капитала и имуществ Общества;

4) сборов по подписным листам и книжкам, допускавшихся, без особого разрешения лишь «под непременным условием отсутствия всякой публичности» (обозначенное условие уже под юридическим соусом выглядит очень расплывчато; в протоколах заседаний попечительных советов и Обществ мы часто встречали решения собрать средства по подписным листам, поручалось это дело в основном людям, входящим в местные общественные организации, например в купеческое собрание, биржевое общество [32, л. 48], однако как реально организовывалась эта подписка неизвестно, хотя с точки зрения здравого смысла понятно, что без публичного оглашения или распространения кулуарных слухов о факте сбора средств на нужды школы в общественной организации, найти необходимые суммы было невозможно);

5) публичных сборов и сборов в кружки, допускаемых с надлежащего каждый раз на то разрешения властей. Кружечные сборы были довольно популярны в дореволюционной России, поскольку позволяли подающему самому определяться с суммой пожертвования, привлекать в качестве жертвователей широкие слои населения. С другой стороны, вскрытие кружки уполномоченным лицом после окончания сборов давало возможность избежать утечки средств, не прибегая к процедуре документирования, как это происходило, к примеру, при пожертвованиях по подписке. Первоначально они использовались в практике подаяний в церквях и храмах денег прихожан в церковные кружки, и постепенно естественным образом были перенесены в практику светской благотворительности. Кружка представляла собой жестяной или иной сосуд, с узкою скважиной в крынке и с замком, для сбора подаяний, для вкладов;

6) доходов от устраиваемых Обществом драматических представлений, литературных чтений, публичных лекций, концертов, лотерей и т.д., с разрешения и с соблюдением соответствующих мероприятию правил его проведения. Так, при устройстве драматических представлений и исполнения на сцене рассказов, стихотворений, куплетов и т.п. требовалась санкция местного полицейского начальства при условии разрешенности этих произведений драматической цензурой при Главном управлении по делам печати. При организации литературных чтений было необходимо разрешение попечителя учебного округа, а произведения должны были быть одобрены цензурой [27, л. 184]. Различные вечера и концерты приносили весьма неплохой доход Обществам. Так, благотворительный концерт, организованный Обществом при СимКУ 16 февраля 1911 г., принес 720,11 руб. чистого дохода, что составило $32 \%$ от всех видов доходов Общества за этот год $[5$, с. 3,7$]$. Поскольку в расходах Общества мы не нашли сумм на организацию концерта, то можно обоснованно предположить, что все траты взяли на себя лично члены Общества, а это не намного меньшая сумма. Если смотреть по аналогии, то, к примеру, на литературно-музыкальный вечер в пользу недостаточных учеников КРУ, проведенный 11 декабря 1905 г. в зале купеческого собрания, было потрачено 371,52 руб., а билетов продано на сумму 735,5 руб., т.е. чистый доход составил 363,98 руб. (сумма чистого дохода оказалась примерно 
равной сумме расходов) [31, с. 72, 73, 79, 82]. Стоит отметить, что вечер этот был организован за три года до создания Общества при КРУ, т.е. данная форма сбора денег для нуждающихся учеников была распространена как эффективный способ благотворительной поддержки и до организации Обществ. Подобные мероприятия по экстренному сбору денег были своеобразной «скорой помощью» для Обществ и самих нуждавшихся учеников, поскольку проводились обычно перед началом сбора оплаты за обучение за полугодие - под новый год или весной.

Bce поступавшие в Общества суммы подразделялись на неприкосновенный и расходный капиталы. Неприкосновенный капитал составлялся из единовременных взносов и пожертвований, сделанных под условием неприкосновенности (т.е. по назначению самих жертвователей), а также части процентов со всех доходов Общества, обычно определявшихся общим собранием. Расходный капитал образовывался из всех прочих поступавших сумм и процентов с неприкосновенного капитала. При этом доходы со специального капитала должны были направляться исключительно на определенное специальное назначение (например, доходы со стипендиальных капиталов направлялись исключительно на стипендии). Во всех Уставах Обществ было прописано, что неприкосновенный капитал, по мере накопления, должен был обращаться в государственные или гарантированные правительством процентные бумаги и храниться в учреждениях Государственного банка (например, в Саратовском отделении Госбанка для Общества при Саратовском Мариинском земледельческом училище), в сберегательных кассах и казначействах; расходный же капитал должен был вноситься на хранение в сберегательных кассах. Получается, что Общества не могли полностью управлять своими финансами, например, делать это более эффективно, чем просто использовать банковский процент. С другой стороны, государство получало само или же предоставляло банковскому миру дополнительные финансовые средства, пусть конечно и не большие, но стоит подчеркнуть понимание властью необходимости вливания в экономику даже таких скромных дополнительных денежных потоков. Отметим, что Общества всячески оттягивали формирование нерационального для их деятельности неприкосновенного капитала, поскольку подобная форма требовала одномоментного вложения и длительного замораживания больших сумм $[2$, с. 6]. На руках у казначея Общества могли находиться только незначительные суммы, определявшиеся общим собранием и необходимые на ближайшие текущие расходы.
Расходование сумм производилось по определению общего собрания или правления (в последнем случае в пределах утвержденных общим собранием смет или согласно особому постановлению сего последнего); в исключительных случаях пособия могли выдаваться председателем правления под его личную ответственность и при непременном условии доведения о том до сведения правления в первое же его заседание [27, л. 183a-184a; 7, с. 7$9 ; 4$, c. 5-7].

К концу XIX в. власти уже осознавали, что привлечение средств и при этом устранение благотворителей от контроля над ними невозможно. Поэтому государство создало правовые возможности для деятельности Обществ. Управление их делами возлагалось на постоянно действующее правление и периодически собиравшееся общее собрание.

В правление входили выборные члены (неодинаковое количество в разных Обществах, избираемые аналогично на неодинаковые сроки, обычно 2-3 года) и непременные члены (представители от учебного заведения - обычно директор и инспектор). Выборы в правление были построены таким образом, что ежегодно часть (1/2 или 1/3) выборных членов заменялась. На случай продолжительного отсутствия или выбытия членов правления ранее срока, общее собрание ежегодно избирало двух-четырех кандидатов, которые заменяли выбивших членов правления до окончания срока их мандатов. Правление из своего состава выбирало председателя, его товарища, казначея и секретаря. Причем Уставы Обществ предусматривали условие, что председателем не мог стать человек, подчиненный в служебном отношении руководителю учебного заведения, т.е. инспектор или преподаватель училища. Должностные обязанности этих лиц вполне стереотипны, поэтому описывать их считаем чрезмерным. Однако следует остановиться на одном важном, хотя поначалу малозаметном факте: годовой отчет о деятельности Общества составлял секретарь, а годовой отчет о суммах казначей. Приглядевшись, можно заметить резкое отличие от составления годовых отчетов школ, которое поручалось их директорам. Скорее всего, такое различие в функционале между директором учебного заведения и председателем правления Общества вспомоществования обусловлено разницей в уровне концентрации власти и ответственности в их руках - директор был своеобразным принципалом (если не сказать точнее - вассальным царьком), а председатель правления - избранным лицом, и, соответственно, отчитывалось правление в целом как коллективный орган, а в школе формально весь груз ответственности висел на директоре. 
Это подтверждается и фактом того, что все отчеты Обществ подписывались полными составами их правлений (см., напр.: [5, с. 20]). Работа в правлении строилась на безвозмездной основе, оплачивались только канцелярские расходы $[12$, с. $7-10 ; 7$, с. $9-10,13-14 ; 4$, с. $7-8,10-$ $11]$.

Правление собиралось по приглашению председателя или по требованию не мене 1/3 его членов. Для действительности постановлений правления было необходимо присутствие не менее половины его членов и председателя. Решение принималось простым большинством голосов, при их равенстве голос председателя давал перевес. Правление занималось решением всех организационных вопросов деятельности Общества, и напрямую оказывало помощь нуждавшимся. Уставы Обществ не прописывали требования о количестве заседаний правлений в год, как, это было для педагогических советов и попечительных советов [20, c. 67, 74]. Большинство из изученных нами отчетов Обществ показало, что правления собирались реже раза в месяц. Так, в 1904 г. правление Общества при КЗУ заседало 4 раза, в 1907 и 1911 гг. при СимКУ - по 1 разу, в 1914 г. при КТШ - 4 раза $[9$, с. 3 ; 6, с. 3 ; 5, с. 3 ; 3, с. 13-18].

В процессе исследования мы обратили внимание на интересный факт. В первом же протоколе заседания правления Общества при КТШ по предложению его члена, инспектора школы Я.А. Александрова было признано желательным приглашение на заседания правления с правом совещательного голоса кандидатов к членам правления, членов ревизионной комиссии и кандидатов к ним и классного наблюдателя М.Д. Прыгунова [3, c. 14]. Суть предложения вполне ясна - учет мнений как можно большего количества членов, соблюдение принципа открытости и коллегиальности решений. Однако, в последующих трех протоколах за 1914 г. кроме М.Д. Прыгунова приглашенных на заседаниях не было. Понятно, что наблюдатель - лицо подневольное, но отсутствие остальных, на наш взгляд, - показатель формального отношения должностных лиц Общества к своим обязанностям.

Правление, по сути, было главным распорядительным органом Общества, тогда как высшим органом управления было общее собрание. Оно могло быть годичным (поскольку должно было собираться не реже одного раза в год) или чрезвычайным (иное название экстренное, для решения неотложных вопросов, неразрешенных правлением или превышавших его власть; собиралось по усмотрению правления, требованию властных структур (обычно МВД и губернатора), ревизионной комиссии или письменному заявлению части членов Общества). На общих собраниях председательствовал один из членов Общества, за исключением членов правления.

Общее собрание считалось состоявшимся, если на нем присутствовала, обычно, хотя бы четверть членов, живших в районе его деятельности. Естественно, обеспечить полную явку всех членов Обществ, особенно иногородних, да и проживавших в том же городе членов, многие из которых были представителями чиновничьей, общественной и финансовой элиты города, было невозможно. Решения принимались простым большинством голосов, кроме вопросов изменения устава, приобретения и отчуждения недвижимой собственности, исключения членов и принятия исключенных вновь в Общество и закрытия последнего, для которых требовалось согласие 2/3 присутствующих. Общие собрания рассматривали вопросы, которые мы подразделили на две группы:

1. организационные. К ним относилось: избрание председателя собрания, почетных членов, членов правления и ревизионной комиссии, а также кандидатов на эти должности; обсуждение и решение вопросов и предложений, представляемых правлением; вопросы изменений и дополнений в устав, закрытия Общества; рассмотрение предложений об устройстве учреждений Общества; исключение из состава и принятие исключенных вновь в состав Общества; утверждение инструкций для правления, ревизионной комиссии и должностных лиц;

2. финансово-хозяйственные или непосредственные: годовой отчет правления, сметы на следующий год и доклад ревизионной комиссии; определение предельного размера пособия, выдаваемого, в случае надобности, по личному распоряжению председателя; образование запасного или специального капиталов; определение суммы на покрытие канцелярских расходов; приобретение и отчуждение недвижимого имущества $[12$, с. $13 ; 7$, c. $17-19 ; 4$, с. 14-15].

Общее собрание должно было рассматривать только вопросы, которые непосредственно относились к определенной уставом деятельности Общества, причем они должны были быть заблаговременно доведены до сведения начальника местной полиции. Жалобы на действия Общества и его членов и предложения высшего начальства должны были обсуждаться в ближайшие сроки на очередном или экстренном собрании, постановление которого должно было немедленно передаваться губернатору и министру внутренних дел.

Каждое Общество имело и финансовоконтрольный орган - ревизионную комиссию, 
состоявшую из трех человек, избираемых ежегодно общим собранием. Она должна была ежемесячно контролировать суммы, имущество и книги Общества, проводить проверку годового отчета и смет, которые для этого должны были передаваться комиссии правлением не менее чем за две недели до общего собрания. Комиссия могла делать незапланированные проверки по своему усмотрению или по письменному, с указанием оснований, требованию определенной части членов Общества. Ревизия должна была проводиться председателем комиссии в присутствии не менее одного ее члена, о результатах проверки делались отметки в обревизованных книгах, а по итогам года комиссия представляла результаты общему собранию [12, с. $15-16$; 7, с. 19-20; 4, с. 15-16].

Все Общества вспомоществования состояли в ведении МВД, имели атрибуты общественной организации: печать с названием Общества, право приобретать и отчуждать недвижимое имущество, заключать договора и сделки, защищать свои интересы в суде, выдавать своим членам билеты и дипломы, удостоверяющие их принадлежность к Обществу. Ежегодные отчеты Обществ должны были подаваться в МВД и губернатору (иногда в министерство, в ведении которого находилось курируемое Обществом учебное заведение). Власть в лице губернатора могла закрыть Общество в любое время, с оговоркой, что его деятельность угрожала общественной безопасности и спокойствию (дефакто, когда Общество занималось делами или обсуждало «неудобные» вопросы, не предусмотренные его уставом) [27, л. 2190-190a; 7 , с. $21-22 ; 4$, с. $16-18]$.

$\begin{array}{rrr}\text { Заключение } & \\ \text { В целом } & \text { можно } & \text { констатировать } \\ \text { положительную } & \text { роль } & \text { Обществ }\end{array}$

вспомоществования в поддержке нуждающихся учащихся. Они оказывали адресную помощь, основанную на принципе информационной достаточности. Хотя нельзя сказать, что этой помощи хватало, к тому же нарушался принцип равенства на ее получение, ставившийся в зависимость от политической благонадежности и поведения ученика, что снижало социальную эффективность благотворительности.

Деятельность Обществ, менее амбициозная и менее заметная, чем учреждение стипендий, была не менее эффективна в обеспечении вертикальной социальной мобильности, так необходимой в переживающей стремительную модернизацию Российской империи. Организованная благотворительность, а не разовые (пусть и значительные) акции отдельных жертвователей создавала благоприятную почву постоянства меценатской деятельности в области образования.

Структура управления Обществами, система выборов, управленческих полномочий и взаимоконтроля их органов как нельзя полно отражали характерные черты политической демократии, отягощенной, однако, государственным регулированием финансовых потоков Обществ и решающей ролью властей в их существовании. Такое противоречивое положение как нельзя более полно характеризует двойственность государственной политики в образовательной сфере. При этом следует признать, что Общества вспомоществования существовали и осуществляли свою деятельность в силу предоставленной властью возможности благотворительной общественности свободно объединять свои усилия.

\section{References:}

1. (1916) Desyatiletie Kazanskogo kommercheskogo uchilishcha. 1905-1915. Kazan'.

2. (1914) Otchet Obshchestva vspomoshchestvovaniya nuzhdayushchimsya uchashchimsya v Kazanskom kommercheskom uchilishche za 1912-1913 uchebnyy god. Kazan': Lito-tipografiya I.N. Kharitonova.

3. (1914) Otchet pravleniya Obshchestva vspomoshchestvovaniya nuzhdayushchimsya uchashchimsya v Kazanskoy torgovoy shkole za 1914 god. Kazan': Tipografiya Tovarishchestva «A.I. Nikitin i Ko».

4. (1914) Ustav obshchestva vspomoshchestvovaniya nuzhdayushchimsya uchenikam Simbirskogo zemlemernogo uchilishcha. Simbirsk: tipografiya Balakishchinova.

5. (1912) Otchet o deyatel'nosti Obshchestva vspomoshchestvovaniya nuzhdayushchimsya uchenikam Simbirskogo kommercheskogo 


\begin{tabular}{|c|c|c|c|c|c|c|}
\hline Impact Factor: & $\begin{array}{l}\text { ISRA (India) } \\
\text { ISI (Dubai, UAF } \\
\text { GIF (Australia) } \\
\text { JIF }\end{array}$ & $\begin{array}{l}=1.344 \\
=0.829 \\
=0.564 \\
=1.500\end{array}$ & $\begin{array}{l}\text { SIS (USA) } \\
\text { PИНЦ (Russia } \\
\text { ESJI (KZ) } \\
\text { SJIF (Morocco }\end{array}$ & $\begin{aligned}= & 0.912 \\
= & 0.179 \\
= & \mathbf{1 . 0 4 2} \\
& =2.031\end{aligned}$ & $\begin{array}{l}\text { ICV (Poland) } \\
\text { PIF (India) }\end{array}$ & $\begin{array}{l}=6.630 \\
=1.940\end{array}$ \\
\hline
\end{tabular}

uchilishcha za 1911 g. Simbirsk: tipografiya N.P. Sidnevoy i Ko.

6. (1908) Otchet o deyatel'nosti Obshchestva vspomoshchestvovaniya nuzhdayushchimsya uchenikam Simbirskogo kommercheskogo uchilishcha za 1907 g. Simbirsk: tipografiya N.P. Sidnevoy i Ko.

7. (1908) Ustav obshchestva vspomoshchestvovaniya nuzhdayushchimsya uchenikam Kazanskogo rechnogo uchilishcha. Kazan': Tipografiya i litografiya A.A. Rodionova.

8. (1907) Kratkie svedeniya o Kazanskom promyshlennom uchilishche i usloviya priema. Kazan': Tipo-litografiya Imperatorskogo Universiteta.

9. (1906) Otchet o sostoyanii i deyatel'nosti Obshchestva vspomoshchestvovaniya nuzhdayushchimsya uchenikam Kazanskogo Zemledel'cheskogo uchilishcha za 1904 g. Kazan'.

10. (1899) Kratkie svedeniya o Kazanskom promyshlennom uchilishche i usloviya priema. Kazan': Tipo-litografiya Imperatorskogo Universiteta.

11. (1898) Obshchestva vspomoshchestvovaniya uchashchimsya $\mathrm{v}$ raznykh uchebnykh zavedeniyakh. Vestnik blagotvoritel'nosti, 7: 50.

12. (1895) Ustav obshchestva vspomoshchestvovaniya nuzhdayushchimsya uchenikam Mariinskogo zemledel'cheskogo uchilishcha. Saratov: Tipo-litografiya P.S. Feokritova.

13. (1888) Ustav obshchestva vspomoshchestvovaniya nuzhdayushchimsya vospitannikam imperatorskogo Moskovskogo tekhnicheskogo uchilishcha. Moskva: Tipografiya Obshchestva rasprostraneniya poleznykh knig.

14. Aminov TM (2006) Dorevolyutsionnaya Ufa kak tsentr professional'nogo obrazovaniya. Ufa: Gilem.

15. Aminov TM (2012) Istoriya professional'nogo obrazovaniya v Bashkirii. Nachalo XVII veka 1917 god. Ufa: Izd-vo BGPU.

16. Cherkasov AA (2011) All-Russian primary education (1894-1917): Developmental Milestones. Social Evolution and History, (2), 10: 138-149.

17. Cherkasov AA (2008) $\mathrm{K}$ istorii nauchnykh i blagotvoritel'nykh obshchestv posada Sochi v nachale XX v. Bylye gody, 3: 3-6.
18. Cherkasov AA (2009) Tsentr i okrainy: kul'turnaya zhizn' posada Sochi v 1894-1917 gg. (po dannym periodicheskoy pechati). Izvestiya Sochinskogo gosudarstvennogo universiteta, 1: 179-185.

19. Gaifutdinov AM, Magsumov TA, Litvin AA, Titova SV (2012) Kak gotovili uchitelei v dorevolyutsionnoi Rossii. Istoricheskie, filosofskie, politicheskie i yuridicheskie nauki, kul'turologiya i iskusstvovedenie. Voprosy teorii i praktiki, 6-2: 49-52.

20. Magsumov TA (2010) Sredniaia professional'naia shkola Kazani v kontse XIX nachale XX veka. Sankt-Peterburg: Izdatel'stvo "Info-da".

21. Molchanova VS, Cherkasov AA, Šmigel' $M$ (2013) Youth and patriotic sentiments during the reign of Emperor Nicholas II. Bylye Gody, (4), 30: 88-93.

22. Natsional'nyy arkhiv Respubliki Tatarstan. Fond 121. Opis' 1. Delo 50.

23. Natsional'nyy arkhiv Respubliki Tatarstan. Fond 121. Opis' 1. Delo 166.

24. Natsional'nyy arkhiv Respubliki Tatarstan. Fond 121. Opis' 1. Delo 291.

25. Natsional'nyy arkhiv Respubliki Tatarstan. Fond 121. Opis' 1. Delo 295.

26. Natsional'nyy arkhiv Respubliki Tatarstan. Fond 121. Opis' 1. Delo 607.

27. Rossiyskiy gosudarstvennyy istoricheskiy arkhiv. Fond 1287. Opis' 19. Delo 2279.

28. Sokolov AR (2005) Blagotvoritel'nost' v narodnom obrazovanii i ee rol' $\mathrm{v}$ transformatsii rossiyskogo obshchestva. Sankt-Peterburg.

29. Titova SV, Litvin AA (2015) Aktual'nye napravleniya sovremennykh istorikoobrazovatel'nykh issledovaniy. $\mathrm{V}$ mire nauchnykh otkrytiy, (5.1), 65: 359-367.

30. Titova SV (2012) Staraya novaya shkola. Istoricheskie, filosofskie, politicheskie i yuridicheskie nauki, kul'turologiya i iskusstvovedenie. Voprosy teorii i praktiki, 1-1: 194-197.

31. Tsentral'nyy arkhiv Nizhegorodskoy oblasti. Fond 1770. Opis' 549. Delo 2.

32. Tsentral'nyy arkhiv Nizhegorodskoy oblasti. Fond 1770. Opis' 549. Delo 20.

33. Tushavin VA, Bobkova EYu (2015) Metodika kvalimetricheskoy otsenki kharakteristik kachestva istoriograficheskikh istochnikov. Sovremennaya nauka: aktual'nye problemy teorii $i$ praktiki. Seriya: Estestvennye $i$ tekhnicheskie nauki, 1-2: 11-16. 